\title{
Response to: Comparison of direct anterior, lateral, posterior and posterior-2 approaches in total hip arthroplasty: network meta-analysis. Eur J Orthop Surg Traumatol, 2017 Sep 27, doi: 10.1007/s00590-017-2046-1 [Epub ahead of print]
}

\section{P. Somford ${ }^{1}$}

Received: 20 November 2017 / Accepted: 1 December 2017 / Published online: 5 December 2017

(c) Springer-Verlag France SAS, part of Springer Nature 2017

Dear Putananon et al.,

With great interest I read your paper on the comparison of different approaches of the hip. Although not per se of influence on the outcome, the eponymous terms used were not correct. The anterolateral approach was stated as the Hardinge approach and the direct lateral approach as the Watson-Jones approach. This needs to be the other way round. Kevin Hardinge used to work with Sir John Charnley and modified the direct lateral trans-trochanteric approach [1] to the straight lateral approach with bisection of the anterior half of the periosteum of the greater trochanter [2]. Watson-Jones described the plane between the tensor fascia lata and the gluteus medius muscle as approach for the hip [3,4].

The danger with eponymous terms lies in a wrong explanation of these terms and should be avoided [5].

Kind regards,

M. P. Somford

\section{Compliance with ethical standards}

Conflict of interest The author declares that he has no competing interests.

\section{References}

1. Charnley J (1979) Low friction arthroplasty of the hip. Theory and practice. Springer, New York

2. Hardinge K (1982) The direct lateral approach to the hip. J Bone Jt Surg Br 64:17-19

3. Watson-Jones R (1936) Fractures of the neck of the femur. Br J Surg 23:787-808

4. Watson-Jones R (1976) Fractures and joint injuries, 5th edn. Churchill-Livingstone, London

5. Somford MP, Nieuwe Weme RA, van Dijk CN et al (2016) Are eponyms used correctly or not? A literature review with a focus on shoulder and elbow surgery. Evid Based Med 21:163-171. https:// doi.org/10.1136/ebmed-2016-110453
M. P. Somford

mp_somford@hotmail.com

1 Ziekenhuis Rijnstate, Arnhem, The Netherlands 